2-13-2018

\title{
Rethinking Patriarchy through Unpatriarchal Male Desires
}

Gul Ozyegin

College of William and Mary, gxozye@wm.edu

Follow this and additional works at: https://scholarworks.wm.edu/asbookchapters

Part of the Gender and Sexuality Commons, and the Women's Studies Commons

\section{Recommended Citation}

Ozyegin, G. (2018). Rethinking Patriarchy through Unpatriarchal Male Desires. Raewyn Connell, Pat Martin, Jim Messerschmidt, and Michael Messner (Ed.), Gender Reckonings: New Social Theory and Research (pp. 233-253). New York: New York University Press. https://scholarworks.wm.edu/asbookchapters/82

This Book Chapter is brought to you for free and open access by the Arts and Sciences at W\&M ScholarWorks. It has been accepted for inclusion in Arts \& Sciences Book Chapters by an authorized administrator of W\&M ScholarWorks. For more information, please contact scholarworks@wm.edu. 
JAMES W. MESSERSCHMIDT

PATRICIA YANCEY MARTIN

MICHAEL A. MESSNER

RAEWYN CONNELL
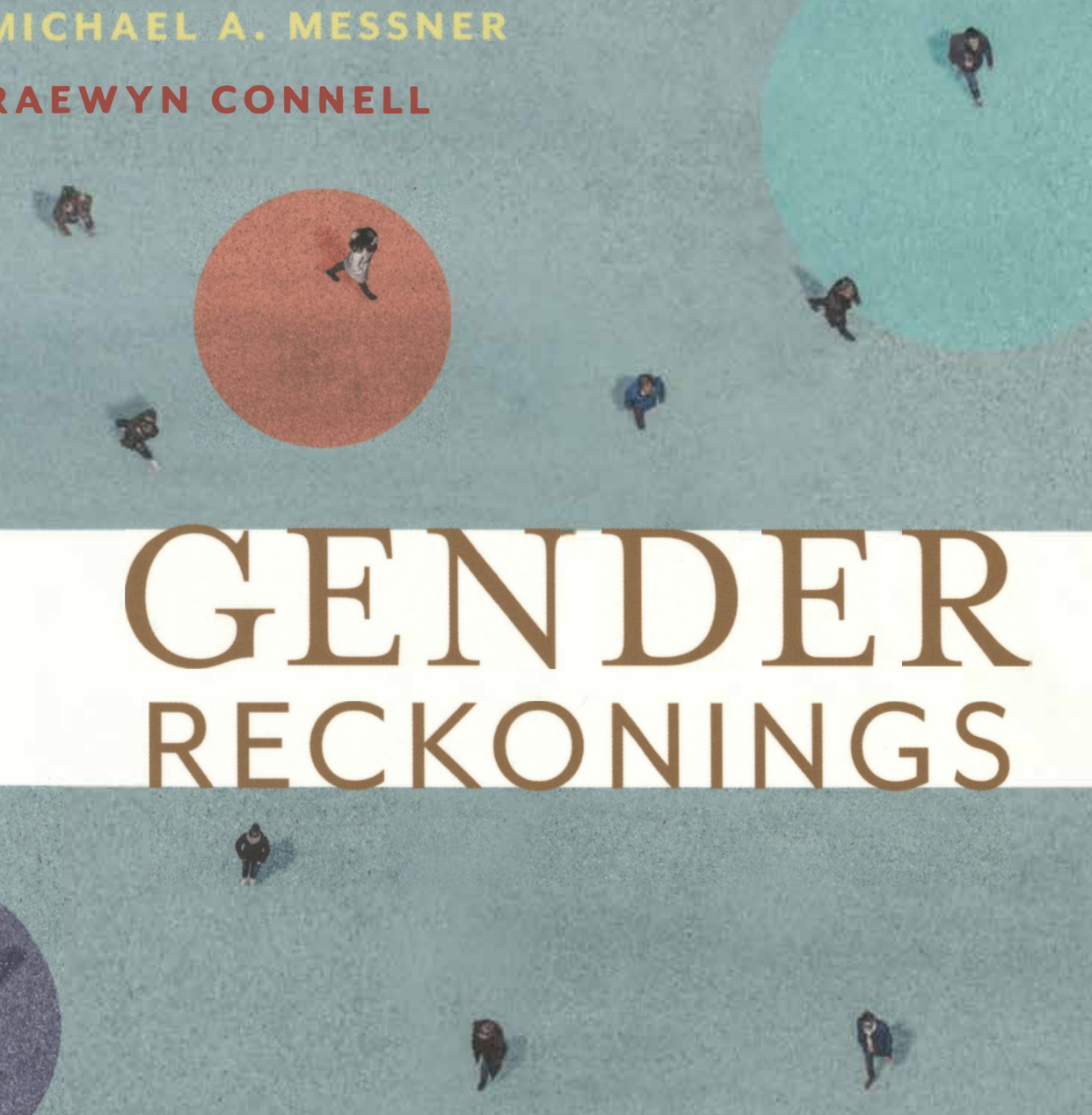

O.

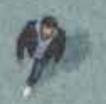

NEW SOCIAL THEORY

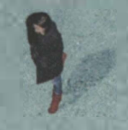

AND RESEARCH

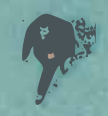

( 


\section{Gender Reckonings}

New Social Theory and Research

Edited by

James W. Messerschmidt,

Patricia Yancey Martin,

Michael A. Messner, and

Raewyn Connell

NEW YORK UNIVERSITY PRESS

New York 


\section{NEW YORK UNIVERSITY PRESS}

New York

www.nyupress.org

C 2018 by New York University

All rights reserved

References to Internet websites (URLs) were accurate at the time of writing. Neither the author nor New York University Press is responsible for URLs that may have expired or changed since the manuscript was prepared.

ISBN: 978-1-4798-9714-8 (hardback)

ISBN: 978-1-4798-0934-9 (paperback)

For Library of Congress Cataloging-in-Publication data, please contact the Library of Congress.

New York University Press books are printed on acid-free paper, and their binding materials are chosen for strength and durability. We strive to use environmentally responsible suppliers and materials to the greatest extent possible in publishing our books.

Manufactured in the United States of America

10987654321

Also available as an ebook 


\section{CONTENTS}

Acknowledgments

vii

Introduction: The Editors

1

PART I. POINTS OF DEPARTURE: GENDER AND POWER AND ITS SEQUELS

1. "Theories Don't Grow on Trees": Contextualizing Gender Knowledge Myra Marx Ferree

2. Hegemonic, Nonhegemonic, and "New" Masculinities James W. Messerschmidt and Michael A. Messner

3. From Object to Subject: Situating Transgender Lives in Sociology

Kristen Schilt

PART II. THE LARGER SCOPE OF GENDER ANALYSIS

4. Postcoloniality and the Sociology of Gender Raka Ray

5. Race, Indigeneity, and Gender: Lessons for Global Feminism Mara Viveros Vigoya

6. Categories, Structures, and Intersectional Theory Joya Misra

PART III. FOUR DIMENSIONS OF RELATIONSHIP, STRUGGLE, AND CHANGE

7. Why "Heteronormativity" Is Not Enough: A Feminist Sociological Perspective on Heterosexuality

Stevi Jackson 
end $r$ Inequality and Femini $m$ in the New Economy

hristine L. Williams and Megan Tobias Neely

9. ender Politic in Academia in the Neoliberal Age

Barbara Poggio

10. The Holy Grail of Organizational Change: Toward Gender Equality at Work

Yvonne Benschop and Marieke van den Brink

PART IV. IYNAMICS OF MASCULINITIES

11. Concerning Tradition in Studies on Men and Masculinities in Ex-Colonies

Kopano Ratele

12. Rethinking Patriarchy through Unpatriarchal Male Desires Gul Ozyegin

13. On the Elasticity of Gender Hegemony: Why Hybrid Masculinities Fail to Undermine Gender and Sexual Inequality

Tristan Bridges and C. J. Pascoe

PART V. AGENDAS FOR THEORY

14. Limitations of the Neoliberal Turn in Gender Theory:

(Re)Turning to Gender as a Social Structure

Barbara J. Risman, Kristen Myers, and Ray Sin

15. Paradoxes of Gender Redux: Multiple Genders and the Persistence of the Binary Judith Lorber

16. The Monogamous Couple, Gender Hegemony, and Polyamory

Mimi Schippers

Conclusion: Reckoning with Gender

Raewyn Connell

About the Contributors

Index 
Rethinking Patriarchy through Unpatriarchal Male Desires

GUL OZYEGIN

Is patriarchy a useful concept for analysis of gender? How should we understand its relation to gender theory? How does the concept of patriarchy as a system of male domination, neither uniform nor static, figure into various domains of gender and gender vocabularies?

I employ the term "rethinking patriarchy" in my title to orient the reader to the particularities of the Turkish case, but more importantly my usage is intended to recall a notable absence in gender theory. I advocate a conceptual framework that can address a missing domain in gender theory: gender domination. When patriarchy was expelled from Northern gender theory as too abstract, too broad, and ahistorical, it seems we also vacated the domain of gender domination altogether from our theorical vocabularly and dropped it from our conceptual toolkit. With the rise of the intersectionality paradigm, ${ }^{1}$ the anaytical power of investigating how gender domination comes to be constituted, maintained, and transformed in particular ways was diminished.

An important category of analysis, patriarchy is notably absent from the burgeoning literature on gender in the West. The hegemonic intellectual categories of gender in contemporary feminist scholarship take us away from explorations of the nature and dynamics of patriarchy. Now the paradigm of intersectionality provides the dominant concepts of gender with a seemingly infinite and flexible capacity to animate research and theory. Postcolonial feminist scholars have pointed out the growing strategic use and transnational circulation of critiques of patriarchy as a strong marker of the boundaries between the global North and South (the absence of patriarchy in the West but the existence of "patriarchy elsewhere") in the service of various economic and political global neoliberalization projects. Indeed, Inderpal Grewal (2013) argues that "patriarchy" has been outsourced to the global South. 
I propose that it would constitute a vital omission to our building of gender theory and politics to leave out of our research and theory the experiences of those individuals who intrinsically link domains of gender to patriarchy and who see themselves, their gender arrangements, and their struggles through a prism of patriarchy.

Like Raewyn Connell, I see a major task in taking account of the theoretical concepts and methods produced in the global South in the elaboration of gender as an analytic paradigm. Connell sees rendering visible theories and concepts produced in the global South and bringing them into the center as the most difficult contemporary challenge to the social sciences in which practices of Eurocentric knowledge production rule. As she puts it cogently, feminist literature "works on the tacit assumption that the global South produces data and politics, but doesn't produce theory" $(2014,520)$. Actively privileging plurality and the permeability of different theoretical voices to allow for the cultivation of a mode of knowledge production, what Connell calls "cross-fertilization," is a formidable task for it hinges on so many radical institutional and political transformations. Cross-fertilization requires forging links that allow understanding connected and mutually constitutive processes and, more importantly, as Connell underlines, recognizing theory and concepts produced in the global South. Seeing, naming, and theorizing the connections, I want to suggest, is also fundamentally dependent on theory embedded in substantive empirical interrogation that captures experience in actually lived terms.

My goal in this chapter is to participate in the effort to build crossfertilization and to deepen the challenges of this concern with an illustration from my research. The task of this chapter is to reevaluate the place of patriarchy in gender theory from the perspective of heterosexual young men in Turkey who are the subjects of, and mediums for, (re)producing patriarchy but who have unpatriarchal desires and struggle to enact unpatriarchal identities and gender practices. It is toward this end that I approach the narratives of love, sex, and self-making the young men shared with me. ${ }^{2}$ These men's narratives provide a useful point of entry for understanding historically and culturally specific configurations of masculinity and patriarchy. Their narrated experiences of sex, love, and romance are telling, constituting a rich site for furthering the theorization of the masculinity-patriarchy nexus, how they come 
together, and how they are uncoupled or recoupled in speech, action, and intimate relations.

Patriarchy as "Elsewhere": The Expulsion of Patriarchy from Northern Theory

Feminist scholars have used the concept of patriarchy as a foundational concept to describe and analyze what they see as simultaneously an ideology, structure, and organizing force in social institutions and practices for women's gender-based subordination and oppression. While the patriarchy paradigm framed many studies in the formative years of feminist scholarship, increasing debates among feminists about how to define the category of "woman" formed a significant impetus for disowning interest in the concept of patriarchy during the last decades of the twentieth century. Black and Third World feminists' challenges to the Euro-American second-wave feminist movement-its construction of white middle class heterosexual women as the "unmarked" subject and object of feminist analysis-generated efforts to theorize differences of race/ethnicity between women and to examine how these differences modify our conceptions of subordination based on gender (Crenshaw 1989; Mohanty 1988; Spelman 1988). The concept of patriarchy has come to be regarded as ahistorical, apolitical, homogenizing, lacking cultural specificity, too abstract, and too broad-an imprecise category not useful in understanding the gender order. It served to underlie white women's oppression to the exclusion of other oppressions, obscuring the complexities of class and racial oppression and Western colonialism.

Out of these concerns, a new paradigm-intersectionality-gained currency, seeming more commensurate with the emergent queer movements, masculinity studies, the global women's movement, and postcolonial feminism. Feminist scholarship has placed the concept of intersectionality at the core of feminist theory and politics, and intersectionality has excited feminist inquiry in many disciplines. Now considered the basic building block of feminist theory, the intersectionality paradigm has, not surprisingly, generated a great deal of discussion regarding how it should be precisely defined and where and how it should be studied (McCall 2005; Davis 2008). The question emerges whether, by using intersectionality as a theoretical tool, we are eliminat- 
ing the analytical power of investigating how each category of difference or inequality comes to be constituted and historically transformed in particular ways.

Two recent articles by postcolonial feminist scholars Inderpal Grewal (2013) and Vrushali Patil (2013) reflect new and productive destabilizations of core assumptions about the decline of patriarchy in feminist scholarship. Grewal notes that while we see an acknowledged abandonment of the concept of patriarchy by theorists in the West, the relevance of patriarchy to describe "others" outside the American-European contexts has been on the rise: "an essentialist notion of the term 'patriarchy' has become naturalized in relation to the 'Global South"'(7), serving to buttress and legitimate all kinds of projects for fiscal gain (including wars waged to save women, as a contemporary version of the saving "brown women from brown men"). Patil (2013) argues that in spite of the wellestablished critiques of the concept of patriarchy, there is an unfinished agenda because much Western feminist writing has evaded the intellectual and political challenges of investigating patriarchies working relationally on a transnational scale and scope. She asks theorists to expand feminist inquiries beyond particular national settings, taking up questions about how patriarchies were and are located in transnational contexts.

\section{The Turkish Case}

Turkey offers a transformative setting for reconsidering patriarchy in gender theory. Historically in Turkey patriarchy and paternalism have been intertwined and the definition of masculinity has been imbued with dominance and a strong emphasis on men's roles as protectors. As such, this specific constellation of patriarchy and paternalism implicates traditional masculinity, like femininity, as "selfless" - a linkage that, as we will see, forms a strong impetus for young men to actively disinherit traditional masculinity and pursue self-consciously unpatriarchal selves. The Turkish case also helps unpack the ways young men come to be invested in romance, over sex, as sources of recognition, challenging our understanding of patriarchal desires and highlighting the importance of incorporating notions of patriarchy in gender theory.

At the present historical moment, we see the coproduction of global neoliberalism and local "neoconservative familialism" (Korkman 2015), 
which together have led to the emergence of a new mode of patriarchy (Coşar and Yeğenoğlu 2011; Kandiyoti 2011; Acar and Altunok 2012) in Turkey. ${ }^{3}$ The Islamist government of the Justice and Development Party (AKP), which hasbeen in power for the last 13 years, promotes a new Turkey that fosters piety based on Sunni Islam by the top-down imposition of Islamic morality. The government advances a pronatalist agenda and policies, prioritizing procreation in heterosexual marriage, actively encouraging early marriage and at least three children, restricting abortion rights, and challenging working mothers to part-time employment and work in the informal economy. In short, the suturing of global neoliberalization with Islamization is a project linked to the fortification of patriarchal familialism. At the same time the strong dissension and resistance to this fortification animates and shapes feminist and LGBTQ movements.

While melding neoliberalism with neoconservatism is remaking patriarchy, during the last two decades the patriarchal underpinnings of law have been marginalized or eliminated. During the early 2000s, a strong feminist campaign within the context of the EU accession process resulted in gender-egalitarian legal and policy reforms that have granted women equal citizenship rights. The new civil code of 2001 equalized the status of husband and wife in the conjugal union by abolishing the concept of the head of family, establishing full equality with respect to rights over the family abode, marital property, divorce, child custody, and rights to work and travel. The new penal code of 2005 reclassifies sexual crimes like rape as crimes against the individual rather than as crimes against "public morality" or "community order."

During this time state paternalism has also undergone a process of dismantling. Historically, the Turkish welfare system has been structured around a patriarchal male-breadwinner family norm in which women's dependence on male protection formed a vital source of security (social security, health insurance, and the pension system). The AKP's reform of the welfare system was instigated by gender-neutral neoliberal policies, with an emphasis on the privatization of the benefits systems. The reforms eliminated women's privileged access to social transfers. However, this dismantling of the paternalistic welfare state is increasing women's vulnerability to economic and social risks precisely because with new economic policies women are being pushed to part-time employment in the formal sector and work in the informal sector that more than ever 
is reinforcing patriarchal gender identities and roles, particularly the valorization of motherhood and caregiving as women's central roles and identities in Turkey, while (re)constructing men as protectors of women (Dayığlu and Başlevent 2012; Toksöz 2012).

The most recent perspectives on men and masculinities in Turkey bring our attention to a crisis of hegemonic masculinity. They highlight the ever-increasing global centrality of neoliberal economic transformations, the newly enacted conservative national policies, the altered forms of the gendered division of labor, fatherhood, and militarism and warfare, and how these processes destabilize the reproduction of hegemonic masculinity. Importantly, these perspectives aim precisely to grasp the native self-understanding and practical realizations of this crisis as they are worked out on the ground. This approach involves an emphasis on subjectivity and attention to the interconnections between the global and local, the role of the state, and how these factors come together to shape the types and forms of (re)negotiations and enactments of masculine identities (Açıksöz 2015; Beşpınar 2015; Özbay 2015).

\section{Imported Vernaculars}

Turkey also provides an important context for discussing the ways experience is retained and theorized in actual analysis. There is considerable distance between theorizations of gender in the North and importation of its terms from English and the vernacular feelings their adaptations create. "Gender" is a relatively recent coinage in Turkey, translated from English. Gender as translated in Turkish is toplumsal cinsiyet, literally meaning "societal sex." Transforming a genderless meaning of sex into gendered toplumsal cinsiyet constructs categories that allow us to speak about socially constructed experiences and identities. However, the specific vernacular feelings toplumsal cinsiyet create are awkward and do not lend themselves to easy mobilization in creating discursivity for social movements. For instance, instead of gender-based inequalities (toplumsal-cinsiyete dayalı eşitsizlik), the feminist movement uses the expression kadın erkek eşitsizliği (inequality between men and women) or erkek devlet (male State). The common vernacular words patriarki or erkek iktidar, (male power or ataerkil, paternal power), on the other hand, allow us to speak about lived experiences. They are versatile 
in referencing perceptions and symbolic inferences, forming a core imaginary and providing the images, norms, and ideals for people's selfunderstanding of their struggles. In short, not gender but notions of patriarchy and practices of patriarchy in creating gender-based system of domination provide a language and symbolism with which to imagine and represent experiences. Thus, the concept/critique of patriarchy is an anchor of local feminist movements and theory. I propose that we should not underestimate the importance of political attachment to patriarchy as a struggle term deployed within feminist/women's movements. It would constitute a vital omission to our building of gender theory and politics to leave out the experiences of those individuals who intrinsically link domains of gender to patriarchy and who see themselves, their gender arrangements, and their struggles through a prism of patriarchy. We should not also underestimate the effective significance of the vocabulary of patriarchy on the ground in contexts in which feminism and its movements have been posed explicitly against patriarchy.

My perspective on theory construction is that theory is produced within a dialogical realm, a form of interpretive and imaginative exchange between the analytical tools we employ and the experiences of the subjects of our studies as narrated to us or observed by us. In order to be locally and politically relevant, feminist theory must both sustain and critique the terms of reference of our ethnographic subjects and their experiences while "also lead[ing] fruitfully beyond it" (Connell 2014, 539). Otherwise, in reference to this discussion here, women and men who believe that their relations are defined by patriarchy find themselves unrepresented, and indeed unpresentable, within a theoretical language devoid of the key terms of patriarchy.

\section{Unpatriarchal Male Desires}

The young men I interviewed came of age amid Turkish society's pivot away from state-based paternalism and have been intensely subjected to the ethos of neoliberalism. Accordingly, they see themselves as embarking on projects of "entrepreneurship of the self" where old ideals of paternal selflessness are replaced by new ideals of masculine individualism, ambition, and pleasure seeking. The young men I spoke with believe that their fathers' lives followed a predetermined teleological 
course imbricated in patriarchal history. Their lives were marked by the conformity of protective paternalism and structured by a patriarchal order that devalued male passion, emotionality, creativity, and authenticity. Although the impact of fathers is complex and dynamic, what remains consistent across the young men's narratives is the sense that adhering to the patriarchal association between masculinity and protection provided their fathers with narrow ranges of identity. By contrast, these young men's identity-making hinges on self-expansion through the invention of new forms of subjectivities, pleasures, and relationships.

As these men reject the patriarchal modes of masculinity modeled by their fathers, they explicitly seek new types of affective relationships with "selfish" women who break with the traditional models of female selflessness embodied by their mothers by privileging their own desires and ambitions. Especially for those upwardly mobile men from traditional family backgrounds who lack suitable others to confer recognition on their new masculine selves, relationships with such women become important sites upon which they confirm the success of their self-making. Yet, as we will see, even as these men seek recognition and support for their own self-making from women who are equally driven and independent, they cannot completely repudiate the maternal model, longing at the same time for "positive" "selfless" girls who subordinate their desires to the needs of the relationship. The tension of this paradox is felt most acutely by men from conservative and rural family backgrounds whose desire to be recognized as desirable and important in intimate relationships with young women who have their own desires for recognition can lead to male domination, jeopardizing these men's projects of creating unpatriarchal male identities.

Precisely because these men are authoring new types of masculine selves, dependent on recognition from suitable others, the desire for intimacy and recognition emerges as more important than the desire for sex in their narratives. The desire for recognition is a powerful formative force in structuring masculinities in a cultural context that steeps desire in a patriarchal tradition, a tradition of motherly devotion and of the privileging and adulation of sons' desires and needs. I examine the terrain of these anxious boundaries and how they are experienced from the point of view of one 23-year-old man: Oktay. ${ }^{4}$ The stories and themes I draw upon from my research in this section bring Oktay into 
the foreground in ways that help make concrete theoretical points about what interrupts or changes the patriarchal construction of masculinity as dominant and protective in Turkish society.

\section{(Re)Making Male Dominance: Oktay’s Story}

In our interview, Oktay declared that "the woman I will marry [will] have a different life than my mother's," signaling his self-conscious and active rejection of paternal masculinity. An ambitious, high-achieving 23 year old, Oktay was raised in a traditional home structured by patriarchal gender and sexual values. According to Oktay, dominating intimate female others is central to his father's identity. Oktay described his mother, a homemaker with limited formal education, as a typical selfless mother. In our interview, Oktay revealed that he does not feel he really knows his mother, a fact he attributed to her total selflessness: "Because, I think, it is not permitted to know her; she makes herself obliterate, puts her desires in the background, because she is someone who sacrifices herself for her children and her husband." Although Oktay blamed larger cultural patterns of male domination and the all-consuming role of motherhood for women's selflessness, he had nevertheless lost personal respect for his mother. As he put it, "I cannot receive [or gain] anything from my mother anymore."

In rejecting his mother's selflessness, Oktay simultaneously rejected the mode of masculinity upheld by his father. His efforts to reflexively constitute an alternative masculinity are thus steeped in a rejection of the mutually reinforcing traditions of selfless femininity and patriarchal masculinity. While away at college he forged a deep desire "not to become like [his] father." One telling motivation in Oktay's self-reimaging was the revelation that his sister did not love his father, something that provoked a fear in Oktay that a future daughter might not love him. Imagining himself as not being loved and admired remained Oktay's emotional point of reference for his romantic aspirations, development, and identity.

Oktay met his girlfriend, Sezen, during their freshman year at Bogazici. According to Oktay, they love each other deeply, and Oktay values her in large part because he can be totally himself around her: "Anything I can experience and feel I can tell her without becoming uncomfortable because I think she understands me. That is, I can let myself 
go." Oktay and Sezen have been together for three years and explore embodied sexuality but haven't experienced sexual coitus. A key episode of their relationship was an eight-month separation, linked, as Oktay put it, to his "curtailment" of Sezen's freedoms. Despite his resistance to inheriting his father's oppressive masculinity, Oktay consistently sought dominance in his relationship with Sezen, disapproving, for instance, of Sezen visiting male friends at their houses to play cards or staying out later than she promised.

Despite his professed rejection of the masculine practices of domination, Oktay's motivation to control Sezen's mobility and relationships arose out of a discourse of masculine protection (the critical but unnamed term in his narrative, I observed). In Oktay's view, Sezen's unsuspecting and warm personality and her inclination to become close with people easily (the exact qualities that made Oktay fall in love with her) rendered her vulnerable and in need of his protection and control. He said that he had no objection to Sezen's socializing and staying out late with friends in their own circle: "She can do anything with friends I know." He saw the issue as Sezen's innocence in dealing with outsiders and her tendency to approach people with open arms without recognizing that men might have ulterior motives.

Oktay also developed an intense preoccupation with what he saw as Sezen's selfishness, which, over time, fostered feelings of insignificance in him. As he put it, "I desire to feel important. . . . I desire for her to respect my values. Maybe even I want her to live by my values." A variety of situations connected with this desire "to feel important" surfaced in Oktay's narrative, indicating that Sezen's "selfishness" was, in Oktay's estimation, a function of her prioritizing her own desires. For example,

even cooking together can be a problem. For instance, she likes spinach and I don't like it. ... I love pasta. She was taking care of the spinach dish when I asked her to watch the pasta, but she didn't hear me because she likes spinach. I coded this as evidence that she doesn't value my desires; she values her own desires.

Oktay's need for Sezen to reassure him that she desired him even extended to the academic environment they share-Oktay reports feeling jealous when Sezen pays too much attention in lecture, ignoring 
him: "We are taking the same classes; she is listening to the lectures, and taking notes. She is disinterested in me during classes." Oktay feels entitled to constant, public assurances that he is at the center of Sezen's attention: "For instance, let's say five of us are studying together and trying to understand something at the same moment. If she understands first, I want her to explain it to me first. That is, I want to know that I am the top priority among other people in her life." Importantly, Oktay values Sezen's attention precisely because she is a modern, unsubordinated woman. She can provide the recognition men like him need to support their new selves - the love, desire, and understanding of a highachieving, independent woman. Yet, paradoxically, these same qualities meant that Sezen prioritized her desires over his, making him feel unimportant, unloved, and, unrecognized.

As dominance is conveyed and practiced within relationships, it can be contested, accepted, challenged, or assimilated with complete acquiescence or all-around conflict. Oktay and Sezen's experience was all-around conflict. Oktay's desire to restrict Sezen's freedom upset her, but, according to Oktay, "She wasn't telling me because she feared that I'd be angry. And because we love each other, we avoid fights." Instead, she apologized for her "transgressions" so as not to upset him. In time, however, "She realized that her freedoms were curtailed and she found herself apologizing to me too much because of my reactions." According to Oktay, she eventually couldn't stand to remain quiescent while her freedoms were subjugated, and she left him.

Oktay's eight-month separation from Sezen helped him gain a critical distance on his relationship. Despite having a brief affair with another young woman during this separation, Oktay was reminded of the exclusiveness of his devotion to Sezen. The separation led him to reassess how he should deal with his intense desire to control her. Knowing he would need to change his behavior in order to rekindle and preserve their romance, he committed to quashing these controlling impulses. Now back together with Sezen, however, he sees himself as keeping his "desires captive in the background." While backgrounding his desires offers Oktay a solution to sustain his relationship, he claimed that he could not help but continue to think about Sezen's selfishness, and this trait haunts him when he envisions his future with her, believing that "in a marital relationship, selfishness would bring harm to the relationship." 
Oktay comes across as brutish and narcissistic, consumed by his desire to be recognized as special and driven by open displays of superiority - when I asked him if Sezen also engaged in another relationship when they were apart, he said that she hadn't but that he wished that she had "for the sake of her understanding of my specialness." This stance can be understood as a specific expression of the more general phenomenon of the desire for recognition: it is symptomatic of an uncertainty of rank and porous dividing lines between different types of masculinities. Oktay lacks familial others with "suitable selves" to confer recognition for the man he wants to become. All he wants to be is a man who is loved and admired by women for his nonoppressive behavior, but this dimension of ideal masculinity is one that neither his oppressive father nor his selfless mother is equipped to affirm. The intimate, gendered other thus becomes crucial to the development of the self-with paradoxical effect.

Oktay's story challenges assumptions we make when we constrain our analysis to the gendered dichotomies of yearning for love and sex that prevail in the literature. Longings for love and sex are not independent from but are in fact complicated by other significant longings-like the longing for recognition. However, as we have seen in Oktay's account, this longing for recognition can lead to masculine domination, when, as Benjamin (1988) suggests, young men wish to be recognized as subjects without returning that recognition. Oktay's story not only highlights practices of domination but may also helps nuance the dialectics of male ambivalence when girls claim selfishness in relationships and refuse to make "meaningful the feelings, actions, and intentions" (Benjamin 1988, 21) of the masculine self.

The path young men, like Oktay, desire to traverse in placing themselves out of patriarchy highlights the potential for the analytic refinement of patriarchy in gender theory.

\section{A Dialogical Approach to Gender}

Connell's theorization of hegemonic masculinity addresses a foundational question in gender theory: What are the relationships between forms of male dominance and gender relations? Her formulation of the concept of hegemonic masculinity is dependent upon and reflects the 
centrality of patriarchy itself. She defines hegemonic masculinity "as the configuration of gender practice which embodies the currently accepted answer to the problem of the legitimacy of patriarchy" $(2005,77)$. Her definition of hegemony in terms of the successful correspondence of "cultural ideal" and collective "institutional power" recognized the significance of the institutional materialization of patriarchy. Furthermore, her stress on "correspondence" gives historicity and specificity to patriarchy, which is determined through specific institutional and organizational forms and underwrites the hegemony of certain groups of men. Her theory also emphasizes how the patriarchal dividend"the advantage men in general gain from the overall subordination of women" (79) - provides the matrix within which hegemony, the distinctive form of domination in the gender order, occurs. In particular, the hegemonic capacities of the dominant form depend on its contribution to men's gender cohesion - that is, the complicity of other, subordinated masculinities (despite their deep contradictions), who benefit from the patriarchal dividend. In other words, patriarchy guarantees (at least in an abstract manner) the universal general interest, advantage, and privilege of all men.

However, Connell's conceptualization of the relationship between hegemony, domination, and femininity remains underdeveloped (a fact she herself acknowledges in a footnote). In her theory, femininity is always organized as an adaptation to men's power $(1987,188)$. She defines "emphasized femininity" as "compliance with subordination" and argues that it "is oriented to accommodating the interests and desires of men" $(1987,183)$. Connell ignored the problem of how different femininities are articulated or dislocated in specific conjunctures across different fields of domination and hegemony. Femininity is thus treated as a residual category and conceptualized with no sustained attention to different forms of patriarchy and women's varied responses to them. Despite the fact that in Connell's theory hegemony, subordination, and complicity as relations are fundamentally rooted and always present in the gender order, an account of how femininity's relationality to masculinity enters into the complex links among hegemony, subordination, and complicity remains unexplored. This lack of attention to femininity results, in Connell's work, in the conflation of hegemony and domination and, perhaps more importantly, undermines a theorization of gender relationally. 
Indeed, it is exactly for this reason that gender scholars who approach their research in various geographies with theoretical tools borrowed from Connell study masculinity and femininity as typologies: hegemonic, complicit, emphasized, exaggerated, marginalized, and subordinated. Furthermore, as Michael Moller (2007) argues, "the conceptual mobility" of these typologies "may also conceal important aspects of the knowledge thus produced; namely the exclusion of those practices, statements and feelings which do not fit this typology of masculine objects" (268). Such practices would include the strong desires of some young men, like Oktay, not to be dominant, controlling, and protective when young men attempt to escape from hegemonic masculinity because it is, like femininity, aligned with selflessness due to the interlinkage of paternalism and patriarchy. As such, this specific constellation of patriarchy and paternalism implicates traditional masculinity, like femininity, as "selfless" - a linkage that, as we will see, forms a strong impetus for young men to actively disinherit traditional masculinity and pursue selfconsciously unpatriarchal selves. In addition to encouraging a limited disciplinary field of vision that overdetermines male identity, changes in the construction of masculinity are often articulated as changes in the relation between masculinities (Collinson and Hearn 1994).

Indeed, explicitly stated in Connell's later work (Connell and Messerschmidt 2005,848 ) is the realization that femininity must be examined not only from the viewpoint of compliance with patriarchy but also from that of the new identities and practices of young women.

I propose a dialogical approach to gender in which gender is theorized relationally. I emphasize the importance of pursuing gender relationally because attention to how practices of domination and subordination are constructed and experienced is important to transforming the relations of domination, and to capturing to the ways women and men contest the boundaries of their transformative capacities both in relation to each other and in relation to the structural and institutional materiality of patriarchy. This is particularly crucial in a societal context like Turkey in which the gender order is destabilized and the stability of hegemonic masculinity is being contested and strongly critiqued in both local practices and discourses like those explored here by young men who question the paternalistic construction of masculinity. 
I apply such a dialogical approach to gender and conceptualize men and women as coproducers of masculine and feminine ideals. I also conceptualize intimate romantic and sexual relationships as sites both for the reproduction of patriarchy and for challenges to it. Romance and sex as an intersubjective terrain shapes young people's perceptions of who they are and generates experiences that reinforce or contradict the enactments of patriarchal gender identities and sexual selves (Ozyegin 2015).

One of the most striking features of the gender transformation across all classes in my larger research is the merging of young men's and women's desires for expanded selfhoods beyond the selflessness implied in both the protective masculine and the maternal feminine models. Men in Turkey are deemed appropriately masculine when they are protective and carry the power to define the boundaries of action and conduct of the girls and women under their protection. The renunciation of this model by young men is propelled by Turkey's neoliberal turn within the context of globalization and the changing structures of career trajectories propelled by massive privatization. However, the building of male self-expansion is organically linked to and dependent on a vision of the feminine other who provokes and nurtures these male desires for layered selves. The male narratives described a vision of desired femininity that was marked by opposing dualities of, on the one hand, ambitious, charismatic, sexually desiring, and self-possessed women and, on the other hand, positive, alturistic, "energy-giving" women.

The emergence of the new definition of masculinity has occurred simultaneously with the appearance of a new construction of femininity among young women. This new femininity constitutes its identity not through maternal roles but through a shared desire for individualized selves defined against other-directedness, self-sacrifice, and female subservience to the desires of others. The desire for self-governance and the rejection of male intrusion on female sovereignty in the name of protection mark the most important constitutive dimensions of the new femininity. Like its male counterpart, this new femininty also has its cocreators. The desired man in the female narratives is constructed dualistically as someone who seeks power and creativity for self-expansion and who has strong ambitions to become a dominant actor in society, 
while simultaneously disavowing gender-based traditional privileges to control and dominate women.

I conclude that these nonpatriarchal gender projects should not be read necessarily as a promise of democratic gender relations. The very notions of desirable femininity, the dialectic between charismatic and engery-giving women in male narratives that would help make expanded male selves possible, might ultimately undermine young women's claims to a new femininity untied to maternal selflessness and female altruism. In the same fashion, the female constructions of ideal masculinity, the dialectic between power in the public sphere and escaping power and domination in intimate relations and the private sphere, might actually serve to undermine female desire for noncontrolling men.

I consider bringing the rich dimensions of "undoing" patriarchy to gender theory as a distinct analytical pathway. This pathway also addresses the methodological question of how we might continue to investigate the link between gender and patriarchy.

\section{Conclusion: From Gender Domination to Rethinking Patriarchy}

Focusing on the identification of selfhood with unpatriarchal values among men raises particular questions and new analytical openings for a feminist theory of gender, lending a valuable paradigm that can reveal the relevance, complexities, and contradictions of the concept of "patriarchy" in gender theory. I have proposed an integration of the language of patriarchy via the example of young men in Turkey who selfconsciously disavow patriarchy and paternalism while simultaneously giving it new forms and subtle expressions. I suggest that their stories cannot be told at all without representing the subjects' explicit engagement with patriarchal ideals and the cognitive and emotional narrative sources that guide their vocabularies. This is not just a challenge for a simple recognition of experience in theory or a claim that experience itself is either a superior or entirely sufficient form for theoretical representation or, as Connell says, "theory is the moment in a larger social process of knowledge formation that transforms data or experience, always in some way moving beyond the given" (Connell 2014, 521).

Focusing on a nation such as Turkey highlights the complex and multifaceted domain of patriarchy and provides strong justification 
for approaches that challenge nation-based boundaries and stress interrelationships rather than ahistorical and preconstituted categories of patriarchy. In particular, it offers an important vantage point from which to view the historical specificities and transformations of Turkish conceptions of patriarchy and state paternalism in relation to global neoliberalism, a complex alignment in the making that is both destroying and remaking the patriarchy-paternalism couple simultaneously in different realms. The ongoing presence of building hegemony to create a new Turkey, the strong resistance to neoconservative patriarchal familialism from feminist and LGBTQ movements, and unpatriarchal desires among young adults offer a transformative setting for a reconsideration of patriarchy in gender theory.

If the aim of gender theory is to generate explanations and imaginaries of change that are indeed politically meaningful and transformative, the basis for achieving that end will depend on its epistemological principles and categories being informed across time, global locations, and cultural particularities. Patriarchy is now conceived as a dangerous traditional form of gender- and aged-based domination that has been supposedly eradicated in the global North, while, as Gwepal illustrates in the quotation with which I begin this chapter, "an essentialist notion of the term 'patriarchy' has become naturalized in relation to the 'Global South.' We must reject the false certainties and the temptation to construct an "epistemological other" in the service of collective projects of domination by the global North. In the same vein, how we deploy conceptions of the "transnational" in relation to patriarchy is important. Limiting the Southern voice to a critique and an exposé (of how contemporary transnational connections operate as neocolonial projects) without tracing in practical terms the real and varying relationships in local patriarchies, which have such a formative place in constructing gender, risks becoming reductive, and actually has the potential to disempower and short-circuit the integration of theories produced by the global South.

In urging a focus on rethinking patriarchy, I am not suggesting that there is an effective universal, singular form of patriarchy that encompasses all gender relations and constructs male power and privilege the same way, and shapes how gender is defined, constituted, identified with, and reproduced. Patriarchy is a particular system of gender domi- 
nation, neither uniform nor static. However, without refining and studying the term "patriarchy," we run the risk of reifying, dehistoricizing, and valorizing patriarchy in the global South and discounting patriarchy in the global North. Critically extending and developing the concept of patriarchy in gender theory makes one more attentive to the project of creating new integrative paths (cross-fertilization, in Connell's terms), by which Southern theory can be incorporated into Northern theory. The Turkish case illuminates the ways in which the concept of patriarchy can help address the incompleteness of gender theory, which currently leaves vast numbers of social actors and political practices thoroughly unaccounted for and constructs a false universalism. It also builds upon the strength of gender theory developed by Connell by providing avenues to address and elaborate the relationality of gender in a more systematic way.

We should devise a theory of gender domination to describe and theorize sites of domination-subordination, practices intimately associated in the creation of gender relations based on domination, finding new ways both to map variations among the domination of men and the subordination of women and to incorporate a focus on interaction/intersection with other systems of domination. Whatever the approach, we must open a thread via gender domination that can provide the anaytical template to link theories produced in different locations that contextualize and particularize gender domination spatially and epistemologically. Gender relations as relations of domination enter into and help to constitute other collective relations and institutional arrangements. Gender domination in gender theory thus provides a larger conceptual canvas and inclusive epistemological and political agenda. The richness that can be garnered from such a theoretical incorporation helps us articulate transformative projects at the systemic macro-structural or institutional level and at the micro-interpersonal or individual level, locally, globally, and transnationally.

\section{NOTES}

1 Originally proposed by black feminists, as way to interpret the effects of race, gender, and class, the intersection theory suggests that instead of looking at race, gender, and class as separate entities, they need to be looked at as interactive, multiplicative, and mutually amplifying experiences and processes that create unique locations of subordination and domination, privilege and disadvantage. Kathy 
Davis (2008) brilliantly argues that it is the very ambiguity and epistemological vacuity and methodological rootlessness of the concept of intersectionality that in fact defines its success. She argues that the concept's undefined parameters powerfully invite inclusion of different epistemological traditions and methodological strategies.

2 In this chapter, I focus on one such narrative. My larger research includes 87 upwardly mobile young adults interviewed between 2002 and 2006 in Istanbul, of which 22 were heterosexually identified men.

3 eoliberalism is considered as a major governing force in the world today, but the concept lacks a precise definition applicable to every case. My usage of this concept is derived from David Harvey who stresses that neoliberalism is better understood as "a theory of political economic practices" that emphasizes that "human well-being can best be advanced by liberating individual entrepreneurial freedoms and skills within an institutional framework characterized by strong private property rights, free markets and free trade" $(2005,2)$. While this definition is illuminating, it needs further explication as the practical implementation of neoliberal policies and practices depends on cultural and historical particularities. For example, in the Turkish version we see a lack of correspondence between neoliberal economic practices and a weakening of the role of the state, in contradiction with one of core neoliberal tenets. During the early 1980 s neoliberalism gained prevalence in Turkey where a privatized and liberalized market economy replaced state-controlled capitalism. Neoliberal transformations are marked by a new economic and cultural configuration and legal changes, broadly characterized by the global opening of markets, a radical process of privatization (selling state-owned enterprises, goods, and services to private companies), and establishing and preserving foreign capital investments. The concept of neoliberalism also includes a perspective on changing notions of selfhood, the production of the presupposed neoliberal subject centered on the ideals of entrepreneurial freedom, self-invention, flexibility, autonomy, and self-realization. Exploration of the complex social, psychological, and material processes that collectively foster the formation of the neoliberal subject now occupies the research agendas of a growing number of scholars across a number of social science disciplines. This chapter situates itself in the framework of this contemporary concern and offers the voices of educationally advantaged young men in Turkey. These men are not only intensely subjected to neoliberal images, ideologies, and institutions but also have the ability to appropriate, reject, or reshape the ethos of neoliberalism in a plurality of contexts.

I use the expression "local neoconservatism" to highlight the wide application of neoliberal policies and the Islamist project of reconstructing patriarchy to control and regulate women's sexuality, labor, and feminine bodily modalities within the context of globalization. It is "neoconservative" because the Islamist government vigorously advocates quite extensive top-down policies to cultivate Islamic piety by focusing on gender relations and sexuality. These 
new state policies are designed to facilitate a pronationalist agenda of sexual reproduction, promotion of (heterosexual) early marriage, gender segregation in the public sphere, and the control and regulation of public life-particularly the elimination of sexually animated environments. Also, the very existence of new gender conservatism in Turkey is a testament to the advances made by the feminists and how they articulated a powerful critique of patriarchal institutions, ideology, and practices.

4 Fictitious name.

\section{REFERENCES}

Acar, Feride, and Gülbanu Altunok. 2012. "The 'Politics of Intimate' at the Intersection of Neo-liberalism and Neo-conservatism in Contemporary Turkey." Women's Studies International Forum 41 (1): 14-23.

Açıksöz, Salih Can. 2015. "In Vitro Nationalism: Masculinity, Disability, and Assisted Reproduction in War-Torn Turkey." In Gender and Sexuality in Muslim Cultures, edited by Gul Ozyegin, 19-37. Burlington, VT: Ashgate.

Benjamin, Jessica. 1988. The Bonds of Love: Psychoanalysis, Feminism, and the Problem of Domination. New York: Pantheon.

Beşpınar, Fatma Umut. 2015. "Between Ideals and Enactments: The Experience of 'New Fatherhood' among Middle-Class Men in Turkey." In Gender and Sexuality in Muslim Cultures, edited by Gul Ozyegin, 95-115. Burlington, VT: Ashgate.

Collinson, D. L., and J. Hearn. 1994. "Naming Men as Men: Implications for Work, Organization and Management." Gender, Work and Organization 1 (1): 2-22.

Connell, R. W. 1987. Gender and Power. Stanford, CA: Stanford University Press. 2005. Masculinities. 2nd ed. Berkeley: University of California Press.

Connell, Raewyn. 2007. Southern Theory. Cambridge: Polity. -2014. "Rethinking Gender from the South." Feminist Studies 40 (3): 518-539.

Connell, Raewyn, and J. W. Messerschmidt. 2005. "Hegemonic Masculinity: Rethinking the Concept. " Gender \& Society 19: 829-859.

Coşar, Simten, and Metin Yeğenoğlu. 2011. "New Grounds for Patriarchy in Turkey? Gender Policy in the Age of AKP" South European Society and Politics 16 (4): 555-573.

Crenshaw, Kimberlé. 1989. "Demarginalizing the Intersection of Race and Sex: A Black Feminist Critique of Antidiscrimination Doctrine, Feminist Theory, and Antracist Politics." In Feminist Legal Theory: Foundations, edited by D. Kelley Weisberg. Philadelphia: Temple University Press.

Davis, Kathy. 2008. "Intersectionality as Buzzword: A Sociology of Science Perspective on What Makes a Feminist Theory Successful." Feminist Theory 9: 67-85.

Dayığlu, Meltem, and Cem Başlevent. 2012. "Gender Aspects of Income Distribution and Poverty in Turkey." In Gender and Society in Turkey: The Impact of Neoliberal Policies, Political Islam, and EU Accession, edited by Saniye Dedeoglu and Adem Elveren, 65-86. London: I. B. Tauris.

Dedeoglu, Saniye, and Adem Elveren, eds. 2012. Gender and Society in Turkey. London: I. B. Tauris. 
Grewal, Inderpal. 2013. "Outsourcing Patriarchy." International Feminist Journal of Politics 15 (1): 1-19.

Hartmann, Heidi. 1981. "The Unhappy Marriage of Marxism and Feminism: Towards a More Progressive Union." In Women and Revolution, edited by Lydia Sargent. Boston: South End Press.

Harvey, David. 2005. A Brief History of Neoliberalism. Oxford: Oxford University Press. Kandiyoti, Deniz. 2011. "A Tangled Web: The Politics of Gender in Turkey." OpenDemocracy, January 5. Accessed October 12, 2014. www.opendemocracy.net.

Korkman, Zeynep. 2015 "Blessing Neoliberalism: Economy, Family, and the Occult in Millennial Turkey." Journal of the Ottoman and Turkish Studies Association 3 (1).

McCall, Leslie. 2005. "The Complexity of Intersectionality." Signs: Journal of Women in Culture and Society 30: 1771-1800.

Mohanty, Chandra Talpade. 1988. "Under Western Eyes: Feminist Scholarship and Colonial Discourse." Feminist Review 30 (Autumn): 61-88.

Moller, Michael. 2007. "Exploiting Patterns: A Critique of Hegemonic Masculinity." Journal of Gender Studies 16 (3): 263-276.

Özbay, Cenk. 2015. “'Men Are Less Manly, Women Are More Feminine': The Shopping Mall as a Site for Gender Crisis in Istanbul." In Gender and Sexuality in Muslim Cultures, edited by Gul Ozyegin, 73-95. Burlington, VT: Ashgate.

Ozyegin, Gul. 2015. New Desires, New Selves: Sex, Love, and Piety among Turkish Youth. New York: New York University Press.

Patil, Vrushali. 2013. "From Patriarchy to Intersectionality: A Transnational Feminist Assessment of How Far We've Really Come." Signs: Journal of Women in Culture and Society 38 (4): 847-867.

Spelman, Elizabeth V. 1988. Inessential Woman: Problems of Exclusion in Feminist Thought. Boston: Beacon Press.

Toksöz, Gulay. 2012. "The State of Female Labour in the Impasse of the Neoliberal Market and the Patriarchal Family." In Gender and Society in Turkey: The Impact of Neoliberal Policies, Political Islam, and EU Accession, edited by Saniye Dedeoglu and Adem Y. Elveren, 47-64. London: I. B. Tauris.

Women for Women's Human Rights. 2002. The New Legal Status of Women in Turkey. Istanbul: WWHER-New Ways.

2006. Turkish Civil and Penal Code Reforms from a Gender Perspective: The Success of Two Nationwide Campaigns. Istanbul: WWHER-New Ways. 